\title{
ON BRAZILIAN SUPRALITTORAL AND BRACKISH WATER SNAILS
}

(Received 6/11/63)

\author{
Eveline \\ $\&$ \\ Ernst Marcus *
}

(With figures 1-9)

On their way from an ancestral marine, probably intertidal, habitat to land and therewith to rich sources of oxygen and vegetable food the Ellobiidae (Pulmonata, Basommatophora) have been favoured by their mode of reproduction. Most of them hatch as young snails, and their velum and operculum are embryonal. Semper (1880; quoted from Pelseneer 1894, p. 114-15) was the first to observe this. Mörch's earlier statement (1867, p. 2) of free-swimming larvae evidently refers to Melampodinae, a subfamily of the Ellobiidae. The vast geographic distribution of $\mathrm{Me}$ lampus over the Indopacific islands led Fischer \& Crosse (1880, p. 21) to suppose free larvae for the species of this genus. The first egg masses of Melampus bidentatus Say were recorded by Hausman (1932), the veligers of several Melampodinae discovered by Morrison $(1953 ; 1958 b)$. One of these is $M$. coffeus (L.), as Dr. Joseph P. E. Morrison kindly informed by letter (November 7, 1962).

Our observations on ellobiids with free larvae refer to $M$. coffeus (Linné, 1758) and Detracia parana Morrison, 1951, both common on the beach of Cananéia $\left(25^{\circ} \mathrm{S}\right)$, where we could work thanks to Dr. Ingvar Emilsson, Director of the Oceanographic Institute, São Paulo, and Dr. Victor Sadowsky, Head of the Research Station. There, in front of the garden, we found egg masses on dead leaves, stones, and pieces of wood in winter (June 1962) and summer (January 1963). Seven to $15 \mathrm{~mm}$ long snails of $M$. coffers were spawning; the exceptional maximum length of our Detracia parana was $7 \mathrm{~mm}$, but already $4.5 \mathrm{~mm}$ long snails are mature. In nature the spawns occur principally at the level

* Caixa Postal 6994, São Paulo. 
of neap tide high water-line. In our dishes set up with material from the shore they were found also on the nearly dry uppermost leaves, whose level corresponds to about spring tide high waterline. Generally two spawns were laid close together, and two snails of $M$. coffeus or $D$. parana sat near them, as if they had mated recently.

According to the different size of mature snails the size of the egg masses varies widely. The roundish, jelly-like clusters of M. coffeus are $1 \mathrm{~mm}$ high, 3-4 mm across, and contain 500-2,000 eggs, each around $80-90 \mu$ in diameter, and enclosed in a capsule about $130 \mu$ long and $92 \mu$ in diameter. In conformity with the smaller size of the snails the egg masses of $D$. parana often contain only about 5-600 eggs, but there were also some larger ones. The capsules are about $110 \mu$ long, $75 \mu$ broad, the eggs $74 \mu$ long and $67 \mu$ in diameter.

At about $30^{\circ} \mathrm{C}$ (January 1963) the veligers of $M$. coffeus hatch after 10-11 days if the spawn is attained by water, if not, they remain in the jelly for some more days. They are colourless, with an average length of $95 \mu$ and breadth of $87 \mu$, have statocysts but neither tentacles nor eyes. The surface of the shell is somewhat rough, especially on the sides; 3 days later the shell had grown to $114 \mu$. The velum is as in the 12 days old embryo of Ovatella myosotis (Meyer 1955, fig. 27). As the smallest crawling snails of $M$. coffeus found had $1.1 \mathrm{~mm}$ long shells, the planktonic life of the veliger is evidently rather long.

Two species which develop to the crawling stage within the egg capsule occur together with the mentioned Melampodinae. These are Blauneria heteroclita (Montagu, 1808) and Ellobium pellucens (Menke, 1830), both of the subfamily Ellobiinae as defined by Morton (1955a, p. 158). With Morrison (1958a, p. 123) we use the name Ellobium, not Auriculastra, for pellucens, and justify this in a forthcoming paper.

Blauneria has a sinistral, up to $7 \mathrm{~mm}$ long shell. Spawns of $2,3,4$, and up to 10 eggs fastened to dead leaves were found in June 1963. They resemble those of Ovatella myosotis (Meyer 1955, fig. 24; Morton 1955b, fig. 21). The largest spawn was 1.6 $\mathrm{mm}$ long, $1 \mathrm{~mm}$ broad; the capsules, each with one egg, as in the other species, measured $0.5-0.56 \mathrm{~mm}$. The diameter of the eggs begins with $0.1 \mathrm{~mm}$ and increased about $10 \mu$ a day (temperature $18-20^{\circ} \mathrm{C}$ ). On the $12^{\text {th }}$ day the embryo was $0.24 \mathrm{~mm}$ long. The small number of big egg capsules containing a large supply of albumen contrasts with the great number of small capsules in the Melampodinae.

On the third day the stage of 64 cells was attained, on the $6^{\text {th }}$ day the embryos rotated, and on the $7^{\text {th }}$ day they had a bilobed velum. First the velum increases in size and is reduced later 
on. After 3-4 weeks the crawling snails hatch. This is a rapid development. It lasts, it is true, twice as long as that of the Melampodinae which leave the capsules as larvae, but this difference of time corresponds to the $10^{\circ} \mathrm{C}$ lower temperature. Evidently the supply of albumen speeds metamorphosis efficiently.

The hatching snail has a lenticular shell, $0.31-0.36 \mathrm{~mm}$ in greater diameter, and consists of one and a quarter of a whorl (Fig. 1). The shell is dextral and reverses its direction to the left with 0.4-0.5 mm (Fig. 2). The larval operculum persists in snails up to $0.68 \mathrm{~mm}$ shell length and is shed with $0.7 \mathrm{~mm}$. The operculum has a process for the attachment of the columellar muscle which does not occur in the larval operculum of the Melampodinae.

The eggs of Ellobium pellucens were not found in nature, but in covered dishes, some containing muddy sand on the bottom, all a great quantity of the blackish undermost parts of the grass mat that shelters the soil at the finding place, pieces of banana stalks and of old wood, and some oyster shells. Moisture was provided with brackish water.

The snails were brought into the dishes at the end of June 1963 and began to lay eggs on September, 12. The spawn is an irregularly wound or partially straight, up to $30 \mathrm{~cm}$ long string of jelly (Figs. 3-4). It contains about 1,000 eggs in a single row. The glittering jelly stuck to grass, banana stalks, and wood. The string is $0.4-0.5 \mathrm{~mm}$ thick, the capsules, whose position is generally oblique, are $0.48-0.5 \mathrm{~mm}$ long and $0.33 \mathrm{~mm}$ in diameter. The eggs measure $0.27 \times 0.19 \mathrm{~mm}$. The capsules are smaller than in Blauneria heteroclita, the eggs bigger, hence the amount of albumen is smaller in $E$. pellucens. This difference becomes even more striking if the size of spawning Blauneria, around $4 \mathrm{~mm}$, is compared with that of Ellobium, $14 \mathrm{~mm}$. The glitter of the egg string disappears after some days, the string becomes discontinuous after 17 days. Then the single capsules lie over one another, no longer in rows.

The embryos gastrulate 24 hours after egg laying, at an average temperature of $23^{\circ} \mathrm{C}$, and on the third day rotate in their capsules. Those of 5 days have a distinct shell, whose great distance from the body is remarkable. On the $7^{\text {th }}$ day the body is $0.2 \mathrm{~mm}$ long, the shell $0.27 \mathrm{~mm}$. From this age to the $16^{\text {th }}$ day the daily growth of the shell is about $10 \mu$. The velum begins inconspicuous and becomes rather large after 18-20 days. From then on it decreases. The embryonic period lasts 4 weeks at the above mentioned temperature.

The size of the emerging snail is about the same as that of Blauneria heteroclita, and development takes about the same time. But the temperature during the observation of Ellobium pellucens 
was higher than that recorded for Blauneria. Hence the rate of development of Ellobium is slower. We do not know the cause of this difference, the bigger eggs, the smaller amount of albumen, or a slower specific rhythm of cell division. The hatched snail (Fig. 6) stands on its short foot, its about $0.35 \mathrm{~mm}$ long shell raised upright. The latter has one and a quarter to one and a half whorl, is sinistral (Fig. 5), and has few distinct narrow growth lines. The swollen top of the tentacle in the adult is preceded by a limited ciliated thickening. Sole and anterior border of the foot are strongly ciliate. A $0.15 \mathrm{~mm}$ long, $0.12 \mathrm{~mm}$ broad operculum (Fig. 7) with a concentric mark bears an about $25 \mu$ long process for the retractor as in Blauneria.

The radula (Fig. 8) is $58 \mu$ long, $46 \mu$ broad, and consists of 17 rows with up to 5.1.5 teeth. These numbers as well as the shape of the teeth differ widely from the adult radula. The form of the rhachidian tooth is similar in several other adult species of the family, but the lateral teeth of the juvenile Ellobium pellucens are peculiar.

Animals of $3 \mathrm{~mm}$ shell length found in nature in June indicate that the observed spring breeding of $E$. pellucens is not the only time of reproduction which occurs in the course of a year. Blauneria heteroclita spawned frequently in our dishes, every time with a maximum of 10 descendants. The reproduction of Melampus and Detracia is the most intense of our 4 species and, as little as that of Blauneria, restricted to a determinate period. Certainly only few larvae of a melampodinan spawn attain the age of metamorphosis and a suitable shore to settle on. Ellobium pellucens, whose numerous eggs produce crawling snails, should be expected to colonize our observed beach intensely. It is, however, rare at all seasons and in nearly all micro-niches. A patchy occurrence in their specific environment is known of many Ellobiidae, and Ellobium pellucens shows this in an extremely high degree. Also the records of its range, W and SW Florida, Guadeloupe, and British Guiana, are scarce for a rather big species known since 1830 and impossible to be confounded with others.

On the place, that we studied, the rarety of Ellobium pellucens might be tentatively explained by a high rate of annihilation of young snails, whose shells up to $10 \mathrm{~mm}$ are much thinner than those of young Melampodinae. Possibly such young snails of $E$. pellucens are often eaten by crabs (Sesarma miersi iheringi Mary J. Rathbun, 1918), very common at the beach of Cananéia. We have only a single observation in favour of this hypothesis, because crabs and snails are nocturnal and hide when illuminated. An $8 \mathrm{~mm}$ shell was found broken as by pincers and still containing rests of the body. Malaysian Sesarma are called omnivorous, chiefly herbivorous (Verwey 1930, p. 182), southeastern African 
species are recorded to prey on the juveniles of other mangrove animals (Macnae \& Kalk 1962, p. 31).

As frequently in the supralittoral fringe of lagoons and estuaries (Morton 1955a, p. 131; Abbott 1958, p. 229), also at Cananéia an Assiminea (Prosobranchia, Rissoacea) is associated with the Ellobiidae. We consider as a subspecies of $A$. succinea (Pfeiffer 1840 , p. 253), to be described elsewhere. Its egg capsules, up to $0.4 \mathrm{~mm}$ in diameter, are fastened singly to dead leaves with a sticky belt. They develop without a planktonic larval phase. At $20-23^{\circ} \mathrm{C}$ young snails hatch in $4-5$ weeks. They measure $0.35-0.36$ $\mathrm{mm}$ in antero-posterior direction and $0.3 \mathrm{~mm}$ from back to foot. This development contrasts with the hatching veligers (Sander, 1950) of A. grayana Fleming, whose development, it is true, was not studied under natural conditions (ibid., p. 149; Fretter \& Graham 1962, p. 401). The European species is more than twice as long (up to $7 \mathrm{~mm}$ ) as ours $(2.9 \mathrm{~mm}$ ), but its egg capsules have only half the diameter $(0.2 \mathrm{~mm})$ of the Brazilian form. These measurements perhaps suggest free larvae as normal stage in the development of A. grayana. On the other hand we obtained prematurely freed swimming veligers of Ellobium pellucens. Their capsules had been accidentally washed into the water in our dish, were taken out and damaged by handling.

Fusiform juvenile nematodes of the order Rhabditoidea are frequent between mantle epithelium and shell of our Assiminea. Such a location is not recorded by Mengert (1953) and Turner \& Pini (1960). The worms are free, neither encysted nor ensheathed, and evidently harmless inquilines.

Our Assiminea lives at levels which are under water only at spring high tides, like A. grayana, whereas the species of Littoridina (Prosobranchia, Hydrobiidae) are water snails and occur, as those of Hydrobia, in marine, brackish and fresh water (Fretter \& Graham 1962, p. 577-83). When their environmental water recedes, e.g., in the upper course of a "mangrove-priel" (= channel, Emery \& Stevenson 1957, p. 678) in the dry season, or at ebb tide on an insolated flat, they burrow into the soft soil and become dormant. We know 3 species of Littoridina from the mangrove region of São Paulo, all eurythermic and euryhaline, as other animals of this habitat. They live in water of different salinity and endure rapid changes of temperature and salt. As not many species tolerate the wide environmental fluctuations in estuaries and lagoons, interspecific competition there is moderate, and the population density of the Littoridina-species is very high (Haderlie \& Clark 1959, p. 465).

The most marine of them, L. australis (d'Orbigny, 1835), has the widest range, from $40^{\circ} 35^{\prime} \mathrm{S}$ to $22^{\circ} 55^{\prime} \mathrm{S}$. We recently described the subspecies L. australis nana Marcus (1963, p. 33 ff.) from 
São Paulo and Rio, and mention only some biological facts here. We have it from coastal sea and brackish water and from a locality where, at least for hours, the water is fresh. It lives on the bottom and among plants. It attaches its single egg capsules $(120 \times 80 \mu)$, each with one egg, with their largest side principally to living shells and opercula of its own species, like Hydrobia ulvae (Henking 1894, p. 91-92). After about 5 days $\left(25^{\circ} \mathrm{C}\right)$ veligers of $120 \mu$ shell length hatch, still without tentacles in contrast with the following species.

Within the range of $L$. australis occurs $L$. charruana (d'Orbigny, 1840), recorded from Montevideo to Santos. Its shell is broader than that of austratis, its osphradium of wavy outlines, not a simple C-shaped band, the communication of the prostate with the mantle cavity is a long duct, not a pore, and a gonopericardial duct, distinct in the female of austratis, was not found in charruana. Whilst $L$. australis australis has up to 7 , australis nana up to 4 penial warts, charruana has up to 16 .

We received some preserved snails of $L$. charruana from the outlet of a lagoon at $30^{\circ} \mathrm{S}$, where the variations of salinity from $34.5 \%$ to $4.5 \%$, exceptionally even $1.5 \%$ may occur within 10 hours in correspondence with tides and winds, as the collector, Mr. Jorge Petersen, kindly informed. In June 1963 masses of Eichhornia and Salvinia drifted along the lagoon Mar Pequeno in front of Cananéia, where some of them stranded. To judge from the nearest beds of these plants they came from the $70 \mathrm{~km}$ distant region of Iguape (for maps see Besnard 1950, p. 9 or Gerlach 1958, fig. 1). Among their roots hundreds of living $L$. charruana were found. In the course of at least 5 days they had passed from oligohaline to polyhaline brackish surface water. Already Ihering (1895, p. 123,128$)$ has recorded $L$. charruana from Iguape found among the rootlike fibres of Salvinia. Our snails had 1-2 eggs with capsules ready to be spawned in the nidamental duct. Young crawling stages with $0.4 \mathrm{~mm}$ shell length and $0.2 \mathrm{~mm}$ long tentacles were found among the roots. The free-swimming larvae evidently remain among the plants, possibly orientated by their tentacles already developed in hatching veligers.

On the sandy seashore that extends over $200 \mathrm{~km}$ between Santos and Cananéia with short interruptions consistent pads of Eichhornia are frequent. If these are driven into the mouth of a coastal creek, its vegetation can be occupied by snails and veligers of $L$. charruana. Thus the range of this euryhaline hydrobiid may be extended by tidal and longshore currents, though it has no true pelagic phase. Where a river valley expands into a coastal plain, and stagnant side waters are formed, wind or flood tides might drive floating plants and the snails and larvae between them upstream and deposit them in such sheltered niches. 
Eggs and swimming veligers were obtained in the laboratory. The measurements of the capsules vary from $125 \times 110$ to $135 \times 85 \mu$. Each contains one egg, $75 \mu$ in diameter. In the standing water of our dishes the capsules were often fastened with their small side to the rootlike fibres of Salvinia, near their base. These fibres also serve as food for the snails. At an average temperature of $20^{\circ} \mathrm{C}$ the veligers hatched in 10 days. They have 2 reddish brown patches on the velum and short primordial tentacles (Fig. 9). The granulated shell is $110 \mu$ long and $90 \mu$ broad.

The river Cubatão, $15 \mathrm{~km}$ landwards from the Bay of Santos, is mentioned among the finding places of $L$. charruana (Pilsbry 1911, p. 558). From there came soil and plants for an artificial mangrove swamp of 12 sq. meters in the botanical garden of the Faculty of Philosophy, São Paulo. Among algae in its slightly brackish shallow water we found a large population of a Littoridina, called $L 3$ here, because its name and morphology will be published elsewhere. Its shell is like that of australis, narrower than that of charruana. The male copulatory organ has a densely ciliated tip which bears a papilla on the convex and a broad hump on the concave side.

The chief vegetation of the alluvial plain north of Santos, where $L 3$ lives, is mangrove; salinity and temperature of its ponds, creeks and rivers vary widely in correspondence with rainfalls, tides, and seasons. In our jars the snails endured slightly brackish as well as coastal sea water $\left(31-34^{\circ} / 00\right)$, tolerated $41^{\circ} \mathrm{C}$ for some hours in dishes with black mud exposed to the sun, and withstood foul water and falling dry for several hours. In fresh water taken from an old aquarium they became rigid rapidly. In the artificial swamp outdoors the snails had laid eggs from August to the beginning of November. After a period of much rain, when their water became nearly fresh, multiplication ceased, and the population regressed. Brought into brackish water in the laboratory, their reproductive activity started again in the course of 48 hours. As in Potamolithus lapidum (d'Orb.) (Ihering 1885, p. 98) and Littoridina tenuipes Pilsbry (1952, p. 52) females outnumber males in $L 3$ ( $2 / 3$ females, $1 / 3$ males). Copulation is accomplished head to head as in $L$. australis nana, or side by side. Often, though less frequently than in Littorina (Ankel 1936, p. 158-59), males try to join with other males. The egg capsules are generally attached as in $L$. a. nana, but in the stagnant water of the swamp and in our dishes they are also fastened to light, movable substrata, empty shells, dead leaves, and algae. The capsules are $0.35-0.38 \mathrm{~mm}$ in greater diameter, hence more than twice the size of those in nana and charruana. The difference of the shell length of the 3 species is much less pronounced, and moreover $L 3$ is intermediate between the bigger charruana and the 
Figs. 1-2 - Blauneria heteroclita. 1. Shell of newly hatched snail. 2. Young shell reversing direction.

Figs. 3-8 - Ellobium pellucens. 3. Part of egg string. 4. Same with higher power. 5. Shell of hatching snail. 6. Crawling young snail. 7 . Operculum of same. 8. Half row of radula of same.

Fig. $\quad 9$ - Veliger of Littoridina charruana. 

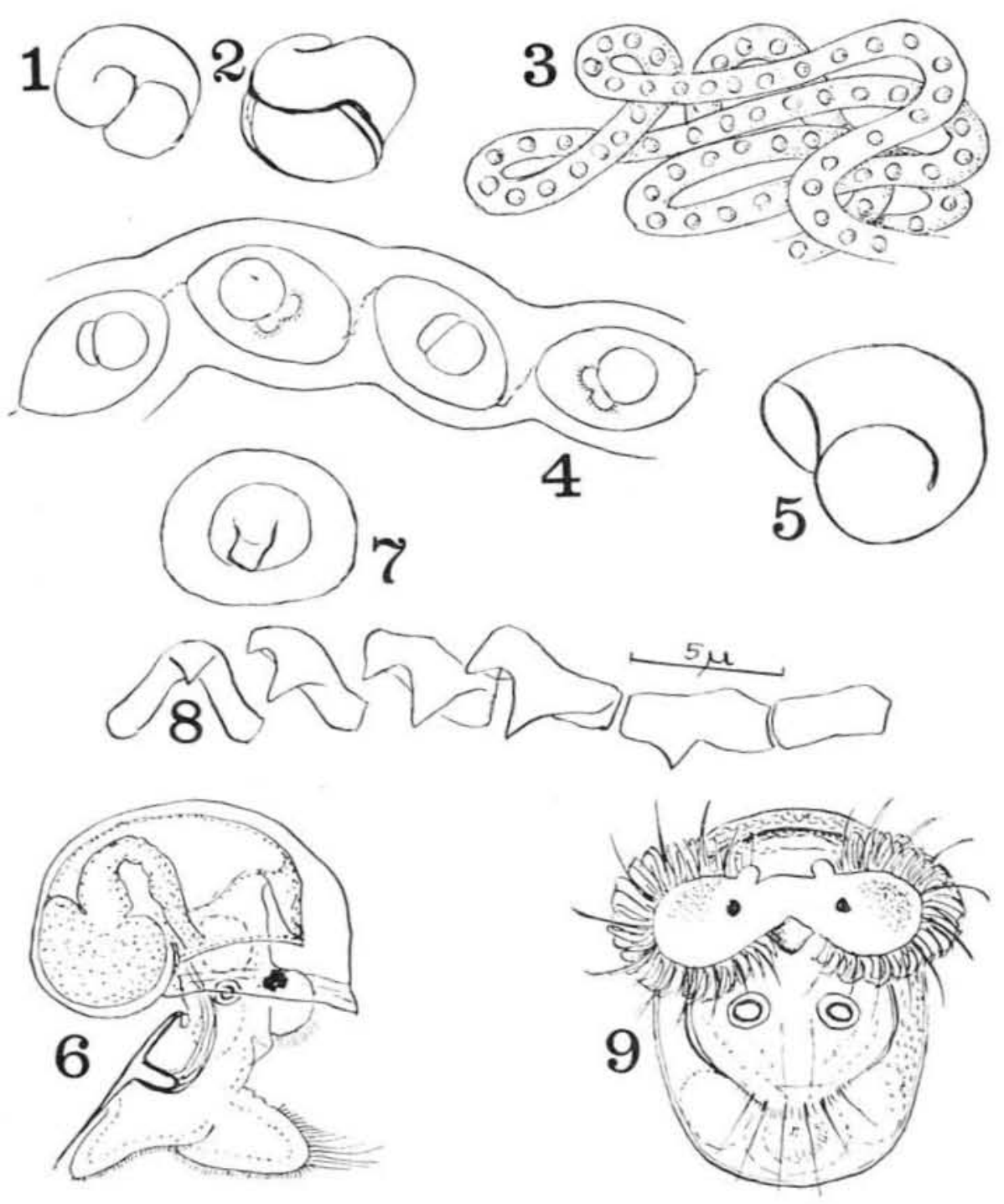
smaller nana. The developmental type of $L 3$ is correlated with its big egg capsule. It contains one egg, $0.18 \mathrm{~mm}$ in diameter, which grows to the size of the capsule, e.g., $0.36 \times 0.3 \mathrm{~mm}$. Crawling snails hatch $L 3$, the veliger stage is passed through within the capsule. This development takes longer: nana hatches in 5 days $\left(25^{\circ} \mathrm{C}\right)$, charruana in $10\left(20^{\circ}\right)$, and $L 3$ in 3 weeks $\left(22-25^{\circ}\right)$. The hatching snail has an osphradium, but no gill. The epithelium of the mantle skirt forms seven $15 \mu$ long projections over the vein in $0.4 \mathrm{~mm}$ long snails; in a $0.6 \mathrm{~mm}$ long animal these gill filaments are $60 \mu$ long.

\section{R ES U MO}

$\mathrm{Na}$ faixa supralitoral de Cananéia $\left(25^{\circ} \mathrm{S}\right)$ as Ellobiidae (Pulmonata, Basommatophora) Melampus coffeus, Detracia parana e Blauneria heteroclita são comuns; Ellobium pellucens é raro. Dos ovos das duas primeiras espécies saem larvas; dos das outras, caracóis. A direção das voltas é sinistral nas conchas dos velígeres e em Ellobium saido do ôvo; dextral em Blauneria, cuja concha é sinistral no caracol adulto. Depois da eclosão, opérculo ainda existe nos jovens caracóis de Blauneria e Ellobium. Associada às Ellobiidae vive uma subespécie do prosobrânquio Assiminea succinea; desenvolve-se diretamente, com véliger apenas embrionário. Dá-se o mesmo com uma das 3 espécies de Littoridina (Prosobranchia, Hydrobiidae) encontradas nas águas dos manguezais; as 2 outras, $L$. australis nana e $L$. charruana, têm larvas que nadam livremente.

R E F ER E N C S

Аввотт, R. T.

1958. The gastropod genus Assiminea in the Philippines. Proc. Acad. nat. Sci., vol. 110 , p. 213-278, pl. 15-25.

ANKel, W. E.

1936. Prosobranchia. In: G. Grimpe \& E. Wagler, Tierwelt Nord\& Ostsee, pars IX b 1, 240 p. Leipzig, Akadem. Verlagsges.

Besnard, W.

1950. Considerações gerais em tôrno da região lagunar de Cananéia. Bol. Inst. Paul. Ocean., vol. 1, n. $^{\circ} 1$, p. 9-26, 1 map.

Emery, K. O. \& Stevenson, R. E.

1957. Estuaries and lagoons. In: Treatise on marine ecology etc., vol. 1, p. 673-693. Washington, D.C., Geol. Soc. America.

Fischer, P. \& Crosse, H.

1880. Auriculidae. In: Recherches zoologiques... Amérique Centrale... Méxique, part 7 , vol. 2, p. $11-30$, pl. 34, 36. Paris, Imprimerie Nationale.

Fretter, V. \& Graham, A.

1962. British Prosobranch Molluscs. xvi +755 p. London, Ray Society. 
Gerlach, S. A.

1958. Die Mangroveregion tropischer Küsten als Lebensraum. Zeitschr. Morphol. Oekol., vol. 46, n. ${ }^{\circ}$ 6, p. 636-730.

Haderlie, E. C. \& Clark, R. B.

1959. Studies on the biology of the Bristol Channel XIX. Proc. Bristol Nat. Soc., vol. 29, n. ${ }^{\circ}$ 5, p. 459-468.

Hausman, S. A.

1932. A contribution to the ecology of the salt marsh snail Melampus bidentatus Say. Amer. Natural., vol. 66, n. ${ }^{\circ} 707$, p. 541545 .

HENKING, H.

1894. Beiträge zur Kenntnis von Hydrobia ulvae und deren Brutpflege. Ber. Naturf. Ges. Freib., vol. 8, p. 89-110, pl. 4.

IHERING, H. v.

1885. Zur Kenntnis der Gattung Lithoglyphus. Malakozool. Bl., vol. 7, p. 96-99.

1895. Die Gattung Paludestrina, Nachr. Bl. dtsch. malakol. Ges., vol. 27 , n. ${ }^{\circ} 7 / 8$, p. $122-128$.

MacNae, W. \& KalK, M.

1962. The ecology of the mangrove swamps at Inhaca, Moçambique. Jour. Ecol., vol. 50, p. 19-34, pl. 1.

Marcus, E. \& E.

1963. Mesogastropoden von der Küste São Paulos. Abh. Math. Naturw. Kl. Akad. Wiss. \& Lit., Mainz, n. ${ }^{\circ}$ 1, p. 1-105.

MengerT, $\mathrm{H}$.

1953. Nematoden und Schnecken. Zeitschr. Morphol. Oekol., vol. 41, n. ${ }^{\circ} 4$, p. 311-349.

Meyer, K. O.

1955. Naturgeschichte der Strandschnecke Ovatella myosotis. Arch. Molluskenk., vol. \$4, n. ${ }^{\circ} 1-3$, p. 1-43, pl. 1-2.

Mörch, O. A. L.

1867. Abrégé de l'histoire de la classification moderne des Mollusques, etc. Jour. Conchyliol., vol. 15, p. 232-258.

Morrison, J. P. E.

1951. Two new species of Western Atlantic mollusks of the genus Detracia and two old ones. Jour. Washing. Acad. Sci., vol. 41 , p. $17-20$.

1953. Demonstration of the egg-masses of Detracia floridana (Pfeiffer). Americ. malacol. Union, Ann. Rep. 6, p. 15-16.

1958a. Ellobiid and other ecology in Florida. Nautilus, vol. 71, n. ${ }^{\circ}$ 4, p. $118-125$.

1958b. The primitive life history of some salt marsh snails. Americ. malacol. Union, 24 $4^{\text {th }}$ Ann. Meeting, September 2-6, 1958. 
Morton, J. E.

1955a. The evolution of the Ellobiidae with a discussion on the origin of the Pulmonata. Proc. zool. Soc. Lond., vol. 125, n. ${ }^{0} 1$, p. 127-168.

1955b. The functional morphology of the British Ellobiidae, etc. Philos. Trans. B, vol. 239 (Biol. Sci., 661), p. 89-160.

Pelseneer, P.

1894. Recherches sur divers Opisthobranches. Mém. cour. Cl. Sci. Nat. Acad. roy. Belg., vol. 53, p. I-III, 1-157, pl. 1-25.

PFEIFFER, L.

1840. Bericht über die Ergebnisse meiner Reise nach Cuba, etc. Arch. Naturg., vol. 6 , n. $^{\circ} 1$, p. 250-261.

PILsBRy, H. A.

1911. Non-marine Mollusca of Patagonia. Rep. Princeton Exp. Patagonia, Zool., vol. 3 , n. ${ }^{\circ}$ 2, p. 513-633, pl. 38-47.

1952. Littoridina tenuipes. Nautilus, vol. 66, n. $^{\circ} 2$, p. 50-54.

SANDER, K.

1950. Beobachtungen zur Fortpflanzung von Assiminea grayana Leach. Arch. Molluskenk., vol. 79, p. 147-149.

Turner, R. D. \& Pini, M. A.

1960. The occurrence of a nematode parasite in the genus Stylodon. Jour. malacol. Soc. Australia, n. ${ }^{\circ}$ 4, p. 56-59, pl. 7.

VERWEY, J.

1930. Einiges über die Biologie ost-indischer Mangrovekrabben. Treubia, vol. 12 , n. ${ }^{\circ}$, p. 169-261, pl. 6-14. 